\title{
Sharing of Personal Sanitary Kits as One Risk Factor of Horizontal Transmission of Hepatitis B among Children Resident at Orphanage
}

\author{
Norma Tiku Kambuno ${ }^{1 *}$ (D), Karol Octrysdey ${ }^{1}$ (D), Kuntum Ekawati Nurdin ${ }^{1}$ (D), Yoan Novicadlitha ${ }^{1}$, Elisabeth N. Barung ${ }^{2}$, \\ Fahmi Hafid ${ }^{3}$ D \\ ${ }^{1}$ Department of Medical Laboratory Technology, Poltekkes Kemenkes Kupang, Kupang, Indonesia; ${ }^{2}$ Department of Pharmacy, \\ Poltekkes Kemenkes Manado, Manado, Indonesia; ${ }^{3}$ Department of Nutrition, Poltekkes Kemenkes Kupang, Kupang, Indonesia
}

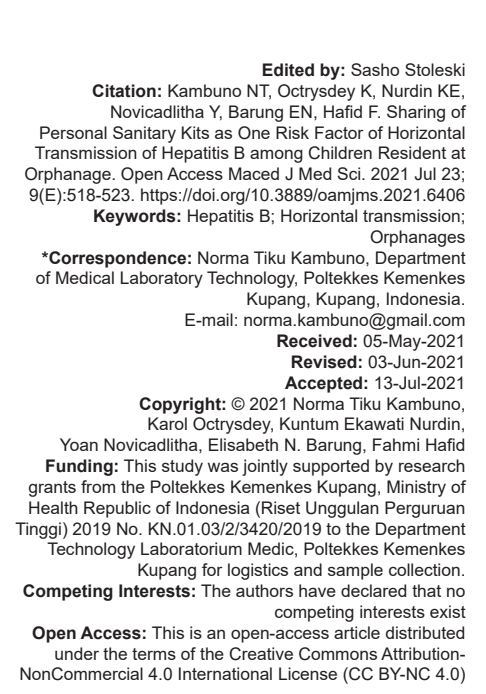

\section{Abstract}

BACKGROUND: Hepatitis B is a disease that infects the liver and is caused by the infection of a hepatitis B virus (HBV), and is becoming a global health issue, especially in developing countries including Indonesia. Hepatitis B can be transmitted through several ways such as infected bodily fluids. Indeed, children who live together in an orphanage are prone to having a high chance of transmitting Hepatitis $\mathrm{B}$ to each other.

AIM: The purpose of this study was to analyze the factors associated with the prevalence of infected Hepatitis B.

METHODS: This research used casecontrol study methodology by taking 15 positive case samples and 33 controlled uninfected patients and was conducted in six orphanages in Kupang Municipality in NTT between July 2019 and November 2019. There were 310 orphanage residents participating in this research.

RESULTS: The research denotes that variables of using a shared toothbrush, nail clipper, and shaver show a significant connection with their Hepatitis B status $(p<0.05)$. A further analysis also indicates that using a shared shaver and toothbrush for 12.6 times has a high risk of being infected by Hepatitis B compared to those who do not share their personal items.

CONCLUSION: Vaccinations and meeting the basic needs of every child in orphanages are essential in order to minimize the risk of Hepatitis $B$ transmission.

\section{Introduction}

Hepatitis $B$ is caused by acute or chronic hepatitis $B$ virus (HBV) infection. It is the most dangerous liver disease compared to other liver diseases due to its lack of apparent symptoms [1]. There are approximately 257 people chronically infected by the HBV, and this virus remains the main infection problem in the world [2]. This can be made worse by complications with cirrhosis and hepatocellular carcinoma that contribute to 887.000 deaths every year [3], [4]. Based on Basic Health Research in 2007, the prevalence of hepatitis B surface antigen ( $\mathrm{HBsAg}$ ) in Indonesia was 9.4\% [5], but this figure declined to $7.1 \%$ in 2013 with 250 million people of total population [6]. This shows that Indonesia has shifted from a highly endemic Hepatitis B country to a moderately endemic country [3], [6].

Several previous studies have reported the prevalence of Hepatitis B in several countries, including on the island of Crete, HBsAg was found to be positive in 29 people, (3.3\%). Antibodies to HBV core antigen were detected in 287 subjects (32.8\%) [7]. Baymakova and Karcheva reported that the morbidity rate of acute HBV infection in Bulagaria was 5.29 cases/100,000 population (95\% Cl: 3.86-6.73) [8]. The Republic of Macedonia has an estimated $\mathrm{HBsAg}$ prevalence of $1-4 \%$ [9] and given that chronic HBV infection is a major pathogen for chronic hepatitis, cirrhosis of the liver, and hepatocellular carcinoma, this poses a serious burden for many countries [10].

According to the Basic Health Research data 2013 [6], NTT is rated one of the provinces that has the highest endemic of Hepatitis B infection, and most of the cases are found in East Sumba and West Sumba. Kambuno et al. state that, according to blood donor data from the Red Cross Indonesia in NTT, the prevalence of Hepatitis B and Hepatitis C in 2017 was 3,5\% and $0,5 \%$ respectively [11]. While Kambuno et al., 2016, reveals that out of 89 people investigated based on their history of living in the same house, 18 respondents were positively infected by the virus $(20.2 \%)$. In 2019 , it was then conveyed that the transmission of Hepatitis $B$ through shared house contact was $15.15 \%(5 / 33)$ in 
Alak sub-district in NTT [1]. During an examination of 63 hemodialysis patients at RSUD Prof. Dr. Johannes Kupang, it was discovered that seven patients had been positively transmitted with HBsAg (11\%) [12].

In addition to being parenterally transmitted (from a mother to the fetus during pregnancy) or mother transmission to children [13], [14]. The HBV can also be horizontally spread to the surrounding environment [15]. People who can be potentially transmitted are usually those who share the same house with the patients [16], prostitutes, drug users, and health workers [17]. Horizontal transmission usually occurs through direct blood contact [18], semen, genital fluid, use of a contaminated syringe, and a shared shaver, nail clipper, and toothbrush [19]. HIV and sexually transmitted diseases represent a significant public health problem worldwide [20].

The fact that the residents of dormitories or orphanages live together as a group and are highly likely to do many daily activities together has increased the risk of Hepatitis $B$ transmission [21], [22]. This can become worse by inadequate housing condition, alternating personal items, and lack of controlling systems from orphanage care. Moreover, the orphans come from a different family background and there is no regular examination into their HBsAg status [23].

Kupang Municipality has at least 25 orphanages with 1100 residents in total. The local government has so far had a concern only about the orphans' food supply but is less focused on their healthcare. The main purpose of this research was to analyze the risk factors of Hepatitis B transmission at orphanages in Kupang. The factors include sex, education background, vaccination status, length of stay at an orphanage, hemodialysis, blood transfusion, receiving injections, dentist visits, history of hospitalization, alternating toothbrushes, nail clippers, and shavers. The results of the study are expected to be a source of information related to the risk factors of hepatitis $B$ transmission and can be used to develop a predictive model of hepatitis $B$ transmission in orphanages.

\section{Methods}

This research used observational methodology control study with a casecontrol study design that analytically studied the causal relationships by making use of inverse logic in order to decide the disease (outcome) first and then identifies the causes (risk factors). The definition of HBV infection in this study was the HBsAg reactive status found at the time of examination without any other tests.

The investigation was conducted from July 2019 to November 2019 among the orphanage residents in Kupang. There were six orphanages involved in this study. The sample measurement employed the formula of calculating the sample population for the casecontrol study design by Lemeshow with a total of 12 cases. In this study, the researchers used 15 positive cases with a comparison of case samples 1: 1 or 1: 2 , depending on the number of children in the orphanages and the number of children who were willing to be interviewed. Inclusion criteria; participants are permanent residents of the orphanage for at least 6 months, recommended by the orphanage manager to become research respondents. Exclusion criteria; not willing to be a respondent.

The sampling technique used in this investigation was multistage non-random sampling. In the first stage, quota sampling was taken from six orphanages and accidental/haphazard sampling was carried out to select certain individuals from each orphanage.

The technique of data collection was an in-depth interview by using a structured questionnaire and creating a friendly and communicative atmosphere. The blood samples were taken from venous blood for approximately $3 \mathrm{cc}$ and collected in EDTA tubes which were separated by serum and then followed by an examination of Hepatitis $B$.

HBsAg tests were performed using Elisa test, Hepanostika HBsAg Ultra (Batch B1V10P01; Biomerieux, Paris, France), simple assay procedure, sensitivity, and specificity are $100 \%$, immunoassay kit according to manufacturer's instructions. Statistical analysis. The baseline data were descriptively summarized. Statistical analyses were performed using Statistical Package for Social Sciences v.20 (SPSS Inc., Chicago, IL), with levels of association assessed by $\chi^{2}$ test. All statistical significance values were assessed at $p<0.05$. Utilizing univariable analysis, the data analysis was conducted to describe the characteristics of the respondents and was presented in form of tables and graphs. The next stage was conducting a bivariable analysis. It was undertaken using the Chi-square test which was employed to verify the hypothesis of a significant effect among risk factors. The next analysis was multivariable analysis where it used a multiple logistic regression test to find out the simultaneous effect of independent variables on dependent variables, and the most independent variables that had the greatest effect on dependent variables.

This research has obtained a research ethic approval from the Health Research Commission, Kupang Health Polytechnic of the Ministry of Health of Indonesia number LB.02.03/1/0045/2019 at September 3, 2019. Every child taking part in this study was asked for their consent and to sign an informed form, or they could be represented by their orphanage caregivers. 


\section{Results}

After the hepatitis status examinations had been conducted, the results indicated that of all 310 respondents participating, 15 respondents were positively infected with HBsAg and 295 were not. The total number of sample data processed in this research was 48 participants with 33 samples were negative and 15 were positive. All the 48 samples are shown in Table 1 about the characteristics of respondents below.

There were 13 variables collected during the interviews and questionnaires, and these were used to investigate the correlation between the variables and their Hepatitis B infection statuses. Answers from the respondents were used to assess the horizontal transmission risks over sharing the same household items that had allowed them to have close contact with the Hepatitis $B$ patients. This habit is evident to have contributed to the contagion of Hepatitis B [1], [24].

Horizontal transmission is one kind of infection transmission of the HBV from a person with Hepatitis $B$ to people in his or her surroundings [24], [25]. One example of horizontal transmission occurs among people who live in the same house, and, specifically for adults, it can happen through several ways such as; contact with blood or blood components; contact with contaminated body fluids from open wounds such

Table 1: Respondents' characteristics of orphanage residents

\begin{tabular}{|c|c|c|}
\hline Characteristic & $\mathrm{n}$ & $\%$ \\
\hline \multicolumn{3}{|l|}{ Sex } \\
\hline Male & 24 & 50 \\
\hline Female & 24 & 50 \\
\hline \multicolumn{3}{|l|}{ Educational qualification } \\
\hline Elementary School & 12 & 25 \\
\hline Middle School & 21 & 43.8 \\
\hline High School & 7 & 14.6 \\
\hline University & 8 & 16.7 \\
\hline \multicolumn{3}{|l|}{ Vaccination status } \\
\hline No & 1 & 2.1 \\
\hline Yes & 47 & 97.9 \\
\hline \multicolumn{3}{|c|}{ Duration of living in orphanages } \\
\hline$<5$ years & 30 & 62.5 \\
\hline$>5$ years & 18 & 37.5 \\
\hline \multicolumn{3}{|l|}{ History of hemodialysis } \\
\hline No/Never & 48 & 100 \\
\hline Yes & 0 & \\
\hline \multicolumn{3}{|c|}{ History of blood transfusion } \\
\hline No/Never & 44 & 91.7 \\
\hline Yes & 4 & 8.3 \\
\hline \multicolumn{3}{|c|}{ History of receiving injection } \\
\hline No & 8 & 16.7 \\
\hline Yes & 40 & 83.3 \\
\hline \multicolumn{3}{|l|}{ History of dentist visits } \\
\hline No & 38 & 79.2 \\
\hline Yes & 10 & 20.8 \\
\hline \multicolumn{3}{|c|}{ History of Hospitalization } \\
\hline No & 40 & 83.3 \\
\hline Yes & 8 & 16.7 \\
\hline \multicolumn{3}{|c|}{$\begin{array}{l}\text { History of using the same } \\
\text { toothbrush }\end{array}$} \\
\hline $\begin{array}{l}\text { toothbrush } \\
\text { No }\end{array}$ & 32 & 66.7 \\
\hline Yes & 16 & 33.3 \\
\hline \multicolumn{3}{|c|}{$\begin{array}{l}\text { History of using the same nail } \\
\text { clipper }\end{array}$} \\
\hline No & 35 & 72.9 \\
\hline Yes & 13 & 27.1 \\
\hline \multicolumn{3}{|c|}{ History of using the same shaver } \\
\hline No & 32 & 66.7 \\
\hline Yes & 16 & 33.3 \\
\hline \multicolumn{3}{|c|}{ History of undergoing a surgery } \\
\hline No & 47 & 97.9 \\
\hline Yes & 1 & 2.1 \\
\hline
\end{tabular}

as bites [26], cuts, and bruises; sharing the same toothbrush, shavers, [27] and diabetes treatment tools [28], [29].

In order to examine the correlation between those 13 variables and their Hepatitis B statuses, bivariable analysis was performed.

The results of this bivariable test indicate that from all 13 variables, only three of them show $p<0.05$. Table 2 shows that the variables that have a significant relationship with infection of hepatitis $B$ are history of using the same toothbrush $(p=0.000)$, history of using the same nail clipper $(p=0.000)$, and history of using the same shaver $(p=0.000)$.

In order to prove how much simultaneous effect these factors had on the virus transmission, a multivariable analysis was conducted. It then resulted in 11 variables not having a simultaneous effect and two variables getting it from a history of using the same shaver and toothbrush.

The results show that the significant value of using the same shaver and toothbrush is $<0.05$ and the Exps(B) value is 12.66, which means that alternating a shaver and a toothbrush has roughly 12.66 chances to be infected with HBV (Table 3).

Table 2: A bivariable analysis on the risk factors of hepatitis B transmission among orphanage residents in Kupang municipality in 2019

\begin{tabular}{|c|c|c|c|c|}
\hline \multirow[t]{2}{*}{ Variables } & \multicolumn{2}{|l|}{ Status $\mathrm{HbsAg}$} & \multirow[t]{2}{*}{ Total } & \multirow[t]{2}{*}{$\mathrm{p}$} \\
\hline & Negative $(n=33)$ & Positive $(n=15)$ & & \\
\hline \multicolumn{5}{|l|}{ Sex } \\
\hline Male & 16 & 8 & 24 & \multirow[t]{2}{*}{0.755} \\
\hline Female & 17 & 7 & 24 & \\
\hline \multicolumn{5}{|l|}{ Educational qualification } \\
\hline Elementary School & 8 & 4 & 12 & \multirow[t]{4}{*}{0.162} \\
\hline Middle School & 16 & 5 & 21 & \\
\hline High School & 6 & 1 & 7 & \\
\hline University & 3 & 5 & 8 & \\
\hline \multicolumn{5}{|l|}{ Vaccination status } \\
\hline No & 1 & 0 & 1 & \multirow{2}{*}{0.496} \\
\hline Yes & 32 & 15 & 47 & \\
\hline \multicolumn{5}{|c|}{ Duration of living in orphanages } \\
\hline$<5$ years & 21 & 9 & 30 & \multirow[t]{2}{*}{0.809} \\
\hline$>5$ years & 12 & 6 & 18 & \\
\hline \multicolumn{5}{|l|}{ History of hemodialysis } \\
\hline No/Never & 33 & 15 & 48 & \multirow[t]{2}{*}{ NA } \\
\hline Yes & 0 & 0 & 0 & \\
\hline \multicolumn{5}{|c|}{ History of blood transfusion } \\
\hline No & 30 & 14 & 44 & \multirow[t]{2}{*}{0.778} \\
\hline Yes & 3 & 1 & 4 & \\
\hline \multicolumn{5}{|c|}{ History of receiving injections } \\
\hline No & 6 & 2 & 8 & \multirow[t]{2}{*}{0.676} \\
\hline Yes & 27 & 13 & 40 & \\
\hline \multicolumn{5}{|l|}{ History of dentist visits } \\
\hline No & 26 & 12 & 38 & \multirow[t]{2}{*}{0.623} \\
\hline Yes & 7 & 3 & 10 & \\
\hline \multicolumn{5}{|l|}{ History of hospitalization } \\
\hline No & 28 & 12 & 40 & \multirow[t]{2}{*}{0.485} \\
\hline Yes & 5 & 3 & 8 & \\
\hline \multicolumn{5}{|c|}{ History of using the same toothbrush } \\
\hline No & 30 & 2 & 32 & \multirow{2}{*}{0.000} \\
\hline Yes & 3 & 13 & 16 & \\
\hline \multicolumn{5}{|c|}{ History of using the same nail clipper } \\
\hline No & 31 & 4 & 35 & 0.000 \\
\hline Yes & 2 & 11 & 13 & \\
\hline History of using the sa & haver & & & \\
\hline No & 30 & 2 & 32 & 0.000 \\
\hline Yes & 3 & 13 & 16 & \\
\hline History of undergoing & gery & & & \\
\hline No & 32 & 15 & 47 & 0.688 \\
\hline Yes & 1 & 0 & 1 & \\
\hline
\end{tabular}




\section{Discussion}

Some previous studies done have shown quite similar results, stating that alternating the same personal belongings such as toothbrushes, shavers, and nail clippers has a significant value related to the status of Hepatitis B infection [30], [31], [32].

Table 3: A multivariable analysis on the risk factors of hepatitis $B$ transmission of orphanage residents in Kupang municipality 2019

\begin{tabular}{llll}
\hline Variables & $\mathrm{B}$ & Sig. & $\operatorname{Exp}(\mathrm{B})$ \\
\hline Sharing a nail clipper & 0.225 & 0.901 & 1.252 \\
Education & 0.844 & 0.210 & 2.325 \\
Sharing a toothbrush & 2.538 & 0.035 & 12.658 \\
Sharing a shaver & 2.538 & 0.035 & 12.658 \\
Constant & -8.188 & 0.000 & 0.000 \\
\hline
\end{tabular}

Talaat concludes that some factors that are significantly correlated to the history of Hepatitis B infection are a history of receiving injections, drug use, having household contact with infected patients, a history of being exposed to invasive medical procedures, and being a military member [33]. On the other hand, Ozer et al. presume that people who have a history of hemodialysis or living together with a positively infected patient (such as a spouse, parents, or siblings) have the highest risk of being transmitted the HBV [31].

Meanwhile, Sali et al., who carried out research into the same subject in Iran, reveals that, from 550 case samples and 434 controlled samples, a number of factors, such as age, sex, marital status, history of having contact with patients, free sex activities, drug injection use, history of a major surgery, history of dental visits, and having certain occupations (police, barber, and driver), show a very close relation with the high risks of Hepatitis B infection [34].

Surprisingly, a history of hemodialysis, blood transfusion, getting injections, dental visits, hospitalization, and undergoing a surgery do not have a significant relationship with the contagion of the HBV. It seems like the causes of the different results above are due to the research population. The samples of the research are mostly children and teenagers with education levels ranging from elementary school to high school. In general, people in these age groups tend to have a lower chance to experience such healthcare history of hemodialysis, blood transfusion, getting injections, hospitalization, or undergoing a surgery [35]. Similarly, there is no remarkable correlation between medical treatment and Hepatitis B infection [30]. However, some studies show that the correlation is significantly present Sali et al. (2005) considering the fact that the respondents are above 16 years old [34].

Horizontal transmission of the HBV is responsible for about half of $\mathrm{HBsAg}$ in Taiwan. A comparison is made between a $\mathrm{HBsAg}$ seronegative mother to an HBsAg carrier child compared to a seronegative child. Factors affecting the transmission are the number of family members, age when starting kindergarten level, frequency of intramuscular injections during infancy and early childhood, contact with HBsAg infected persons, and parents' and siblings' HBV statuses [36]. HBsAg represents a significant prognostic marker in means of disease outcome, not only in the natural history but also during the antiviral treatment of chronic HBV infection [10].

A history of receiving an injection is proven to have a strong relationship with the HBsAg infection status [33]. Dental checkups and receiving invasive measurements in dental care are of a high risk of Hepatitis B and C spread [32].

It is clear that inadequacy of basic necessities and food supply has been the main cause of Hepatitis $B$ transmission in orphanages. It is then suggested that the government should pay more attention to the orphanages and give vaccinations and $\mathrm{HBO}$ immunizations free of charge to the 295 other residents who are not infected.

Another contributory factor to the Hepatitis B transmission is occupying a room shared by 10-20 people. That is why meeting the daily needs of orphanage children is of high importance since the insufficiency of personal items such as toothbrushes, nail clippers, shavers, towels, and soap has made them share those items for quite a long period of time. This has consequently led to the higher risk of virus transmission.

Most of the 310 participants interviewed during the research admitted that they did not have their own toothbrushes and most males had to share a shaver with their roommates. The lack of financial support has been the leading cause of fulfilling their needs, and this has subsequently forced the children to share their personal items.

Some further information gathered from interviews with the management of the orphanages reveals that the local government has never undertaken preventive programs such as regular vaccinations and medical checks, sanitary information day, and initial health screening before a child is accepted into an orphanage. This research has some limitations that need to be addressed. Since only the ELISA test was used for the detection of HBV antibodies without confirmatory testing, the results and the conclusions should be interpreted with caution. Moreover, the research included a relatively small number of participants. Despite these limitations, this research gives new insights for this infection in our country.

\section{Conclusion}

Vaccinations for orphanage children are extremely essential, especially for those who are not 
infected with HBsAg (295 respondents). Besides, the fulfillment of basic necessities of the orphanage residents should be the main concern in order to diminish the risks of Hepatitis B transmission.

\section{Acknowledgments}

We would like to thank Dr. R.H. Kristina SKM, M.Kes, Director of Poltekkes Kemenkes Kupang. Hereby, the researchers gratefully thank to the management of the orphanages, children, and all people who helped us to conduct this study. We would also express sincere gratitude to all the subjects for their participation in this study. Special thanks are given to Dr. Ferry Efendy from Airlangga University in Surabaya for proofreading this manuscript and fruitful discussions.

\section{References}

1. 1. Kambuno NT, Bessie MF, Tangkelangi M. Risk factors of intra-familial hepatitis $B$ virus transmission among hepatitis $B$ patients in kupang. Glob Med Health Commun. 2019;7(2):1505. https://doi.org/10.29313/gmhc.v7i2.4149

2. World Health Organization. Global Health Sector Strategy on Viral Hepatitis 2016-2021. Global Hepatitis Programme Department of HIVIAIDS. Geneva: World Health Organization; 2016. p. 56.

3. le SI, Turyadi, Sidarta E, Sadhewa A, Purnomo GA Soedarmono YS, et al. High prevalence of hepatitis B virus infection in young adults in Ternate, Eastern Indonesia. Am J Trop Med Hyg. 2015;93(6):1349-55. https://doi.org/10.4269/ ajtmh.15-0331

PMid:26392157

4. Darmawan E, Khobar KL, Turyadi, Nursanty NK, Thedja MD, Muljono DH. Seroepidemiology and occult hepatitis B virus infection in young adults in Banjarmasin, Indonesia. J Med Virol. 2012;87(2):199-207. https://doi.org/10.1002/jmv.24045 PMid:25521058

5. Badan Penelitian dan Pengembangan Depkes RI, Rise Kesehatan Dasar Departemen Kesehatan Republik Indonesia, Riskesdas, Depkes RI. Lembaga Penerbit Badan Penelitian dan Pengembangan Kesehatan. Indonesia: Badan Penelitian dan Pengembangan Depkes RI; 2007. https://doi.org/10.14203/ press.298

6. Badan Penelitian dan Pengembangan Kesehatan. Riset Kesehatan Dasar 2013. Riskesdas. Jakarta: Lembaga Penerbit Badan Penelitian dan Pengembangan Kesehatan; 2013. p. 1-384. https://doi.org/10.14203/press.298

7. Drositis I, Bertsias A, Lionis C, Kouroumalis E. Epidemiology and molecular analysis of hepatitis A, B and C in a semi-urban and rural area of crete. Eur J Intern Med. 2013;24(8):839-45. https://doi.org/10.1016/j.ejim.2013.08.003 PMid:23988264

8. Baymakova MP, Karcheva M. Trends in the acute hepatitis B and acute hepatitis C in Bulgaria. Folia Med. 2019;61(2):197203. https://doi.org/10.2478/folmed-2018-0076

\section{PMid:31301665}

9. Dimzova M, Bosilkovski M, Kondova-Topuzovska I, Gaseva M, Toshevki B, Petreska B, et al. Characteristics of an outpatient cohort with HBeAg-negative chronic hepatitis B. Open Access Maced J Med Sci. 2019;7(13):2068-74. https://doi.org/10.3889/ oamjms.2019.623

PMid:31456827

10. Dimzova M, Kondova-Topuzovska I, Milenkovic Z, Gaseva M, Chaloska-Ivanova V, Serafimoski V, et al. Clinical significance of quantitative HBs antigen in the prediction of liver fibrosis in patients with chronic hepatitis B. Pril. 2018;39(1):51-8. https:// doi.org/10.2478/prilozi-2018-0023

PMid:30110270

11. Kambuno N, Sari A, Nurdin K, Novicadlitha Y, Siregar I. The relation of blood donors' characteristic toward prevalences of HBsAg and Anti-HCV on blood transfussion unit of PMI in Province of East Nusa Tenggara. In: Waangsir F, Kase S, editors. Proceeding $1^{\text {st }}$ International Conference Health Polytechnic of Kupang. Kupang, East Nusa Tenggara: Health Polytechnic of Kupang; 2018. p. 303-10. https://doi.org/10.26911/mid. icph.2018.01.20

12. Irfan I, Wawomeo A, Kambuno NT. Hepatitis B virus infection in hemodialisis patient at Prof. DR. W.Z. Johannes Kupang hospital, East Nusa Tenggara. J Kesehatan Prim. 2019;4(1):63-9.

13. Dabsu R. Seroepidemiology of hepatitis B and C virus infections among pregnant women attending antenatal clinic in selected health facilities in East Wollega Zone, West Oromia, Ethiopia. Biomed Res Int. 2018;2018:4792584. https://doi. org/10.1155/2018/4792584

PMid:30643809

14. Kanji JN, Penner RE, Giles E, Goodison K, Martin SR, Marinier E, et al. Horizontal transmission of hepatitis $B$ virus from mother to child due to immune escape despite immunoprophylaxis. J Pediatr Gastroenterol Nutr. 2019;68(5):81-4. https://doi. org $/ 10.1097 / \mathrm{mpg} .0000000000002318$ PMid:30889137

15. Azarkar G, Doosti Z, Osmani F, Ziaee M. Analysis of risk factors for nonalcoholic fatty-liver disease in hepatitis $B$ virus infection: A case-control study. Hepat Med. 2019;11:153-8. https://doi. org/10.2147/hmer.s211106 PMid:31749640

16. Paquet C, Babes VT, Drucker J, Senemaud B, Dobrescu A Viral hepatitis in Bucharest. Bull World Health Organ. 1993;71(6):781-6.

PMid:8313496

17. Meriki HD, Emmanuel T, Tony NJ, Malika E, Bolimo AF, Kouanou YS, et al. HBV transmission risk assessment in healthcare workers, household and sexual contacts of HBV infected patients in the Southwest region of cameroon. Oman Med J. 2019;34(4):313-21. https://doi.org/10.5001/omj.2019.62 PMid:31360320

18. Sali $\mathrm{S}$, Azarmmanesh $\mathrm{S}$, Ghalikhani $\mathrm{H}$, Vaezjalali $\mathrm{M}$ Phylogenetic analysis of hepatitis $B$ virus among household members with HBV chronic infection. Avicenna $J$ Med Biotechnol. 2019;11(3):221-8.

PMid:31379994

19. Katoonizadeh A, Motamed-Gorji N, Sharafkhah M, Ostovaneh M, Esmaili S. IRANIAN intra-familial transmission of chronic hepatitis B infection: A large population-based cohort study in Northern Iran. 2018;21(10):436-42. PMid:30415551

20. Vilibić-Čavlek T, Kolarić B, Pavlić J, Kosanović-Ličina ML, Nemeth-Blažić T. Seroprevalence and risk factors for HIV, hepatitis $B$, and syphilis in populations with high-risk behaviors in croatia. Acta Dermatovenerol Croat. 2018;26(4):3147-320. 


\section{PMid:30665481}

21. Rajamoorthy $Y$, Taib NM, Munusamy S, Anwar S, Wagner AL, Mudatsir $\mathrm{M}$, et al. Knowledge and awareness of hepatitis $\mathrm{B}$ among households in Malaysia: A community-based crosssectional survey. BMC Public Health. 2019;19(1):1-11. https:// doi.org/10.1186/s12889-018-6375-8 PMid:30630464

22. Khan $\mathrm{T}$, Jung $\mathrm{IH}$, Khan $\mathrm{A}$, Zaman G. Classification and sensitivity analysis of the transmission dynamic of hepatitis B. Theor Biol Med Mod. 2017;14(1):1-17. https://doi.org/10.1186/ s12976-017-0068-3

PMid:29202763

23. Shedain PR, Devkota MD, Banjara MR, Ling H, Dhital S. Prevalence and risk factors of hepatitis $B$ infection among mothers and children with hepatitis B infected mother in upper Dolpa, Nepal. BMC Infect Dis. 2017;17(1):1-9. https://doi. org/10.1186/s12879-017-2763-4

24. Alizadeh $\mathrm{AH}$, Ranjbar M, Ansari S, Alavian MS, Shalmani MH, Hekmat L, et al. Intra-familial prevalence of hepatitis B virologic markers in HBsAg positive family members in Nahavand, Iran. World J Gastroenterol. 2005;11(31):4857-60. https://doi. org/10.3748/wjg.v11.i31.4857

PMid: 16097058

25. Salkic NN, Zerem E, Zildzic M, Ahmetagic S, Cickusic E, Ljuca F. Risk factors for intrafamilial spread of hepatitis $B$ in Northeastern Bosnia and Herzegovina. Ann Saudi Med. 2009;29(1):41-5. https://doi.org/10.4103/0256-4947.51821

PMid:19139614

26. Aomatsu T, Komatsu H, Yoden A, Hosomi A, Miyazaki H, Sogo T, etal. Fulminanthepatitis B and acute hepatitis B due to intrafamilial transmission of HBV after chemotherapy for non-Hodgkin's lymphoma in an HBV carrier. Eur J Pediatr. 2010;169(2):16771. https://doi.org/10.1007/s00431-009-1000-6 PMid:19466454

27. Sofian M, BanifazIM, Ziai M, AghakhaniA, FaraziAA, RamezaniA. Intra-familial transmission of hepatitis B virus infection in Arak, central Iran. Iran J Pathol. 2016;11(4):328-33. https://doi. org/10.26226/morressier.56d5ba29d462b80296c96410 PMid:28855924

28. Pereira VR, Wolf JM, Luz CA, Stumm GZ, Boeira T, Galvan J, et al. Risk factors for hepatitis B transmission in South Brazil. Mem Inst Oswaldo Cruz. 2017;112(8):544-50. https://doi. org/10.1590/0074-02760170043

PMid:28767979

29. Persson A, Newman CE, Hamilton M, Bryant J, Wallace J, Valentine K. Families living with blood-borne viruses: The case for extending the concept of serodiscordance. Interdiscip Perspect Infect Dis. 2017;1:1-10. https://doi.org/10.1155/2017/4352783

30. Talaat M, Radwan E, El-Sayed N, Ismael T, Hajjeh R, Mahoney FJ. Case-control study to evaluate risk factors for acute hepatitis B virus infection in Egypt. Eastern Mediterr Health J. 2010;16(1):4-9. https://doi.org/10.26719/2010.16.1.4 PMid:20214150

31. Ozer A, Yakupogullari Y, Beytur A, Beytur L, Koroglu M, Salman $F$, et al. Risk Factors of hepatitis B virus infection in Turkey; a population-based, case-control study. Hepat Mon. 2011;11(4):263-8. PMid:22087152

32. Mahboobi N, Porter SR, Karayiannis P, Alavian SM. Dental treatment as a risk factor for hepatitis $B$ and $C$ viral infection. A review of the recent literature. J Gastrointestin Liver Dis. 2013;22(1):79-86.

PMid:23539395

33. Akhtar S, Younus M, Adil S, Hassan F, Jafri SH. Epidemiologic study of chronic hepatitis $B$ virus infection in male volunteer blood donors in Karachi, Pakistan. BMC Gastroenterol. 2005;5:1-9. https://doi.org/10.1186/1471-230x-5-26 PMid: 16086833

34. Sali S, Bashtar R, Seyed A. Risk factors in chronic hepatitis B infection: A case-control study. Hepa Mon. 2005;5(4):109-15.

35. Zhao M. Efficacy of antepartum administration of hepatitis $B$ immunoglobulin in preventing mother-to-child transmission of hepatitis B virus. J Viral Hepatol. 2019;26(9):1059-65. https:// doi.org/10.1111/jvh.13123

PMid:31087455

36. Hsu SC, Chang MH, Ni YH, Hsu HY, Lee CY. Horizontal transmission of hepatitis B virus in children. J Pediatr Gastroenterol Nutr. 1993;16(1):66-9. https://doi. org/10.1097/00005176-199301000-00012

PMid:8433243 